\title{
Comparison of Single Incision Laparoscopic and Classic Stamm Gastrostomy Methods in Children
}

\author{
Çocuklarda Tek Kesi Laparoskopik ve Açık Yaklaşım Gastrostomi Yöntemlerinin Karşılaştırılması
}

\author{
Murat KABAKLIOĞLU \\ (D) 0000-0002-2894-0470 \\ Murat KAYA \\ (D) 0000-0001-6650-0145
}

Düzce University Medical Faculty, Department of Pediatric Surgery, Düzce, Turkey

\section{Corresponding Author Sorumlu Yazar \\ Murat KABAKLIOĞLU}

mkabaklioglu@yahoo.com

Received / Gelis Tarihi : 04.09.2020 Accepted / Kabul Tarihi : 26.11.2020 Available Online /

Çevrimiçi Yayın Tarihi : 25.12.2020

\begin{abstract}
Aim: The aim of this study was to compare single incision laparoscopic gastrostomy (SILG) with open surgery in children.

Material and Methods: Children who underwent laparoscopic and open gastrostomy surgeries between January 2016 and March 2020 were retrospectively evaluated. The data were arranged according to the patient's demographics, duration of surgery and anesthesia, time to start enteral feeding, and complications. For Stamm procedure, the abdomen was explored with an upper midline incision and a gastric tube was passed through a second incision. In the SILG method, only one incision was made. After inserting a camera was placed into a trocar, then a grasper was placed just next to the trocar. A part of stomach was removed through the incision. A foley catheter was placed visually into the lumen.

Results: There was no statistically significant difference between operation times for both surgical groups $(\mathrm{p}=0.844)$; the same was true for anesthesia times $(\mathrm{p}=0.919)$. The time taken to initiate and reach full enteral nutrition differed significantly between two groups $(\mathrm{p}=0.005)$. In general, when all complications were evaluated, more complications were found in the open surgery group $(\mathrm{p}=0.077)$. A remarkable number of maintenance problems $(65.6 \%)$ were observed in both groups.

Conclusion: SILG is a technique that is not technically demanding and can be performed by any pediatric surgeon with experience in laparoscopy. Primary laparoscopic gastrostomy at the trocar insertion site can be performed easily and safely in all children with malnutrition due to low postoperative complication rates and applicable for all ages of children.

Keywords: Single incision laparoscopic gastrostomy; Stamm gastrostomy; children.
\end{abstract}

ÖZ

Amaç: $\mathrm{Bu}$ çalışmanın amacı çocuklarda tek insizyonlu laparoskopik gastrostomi (single incision laparoscopic gastrostomy, SILG) ile açık cerrahinin karşılaştırılmasıdır.

Gereç ve Yöntemler: Ocak 2016 ve Mart 2020 tarihleri arasında laparoskopik ve açık gastrostomi ameliyatı geçiren çocuklar geriye dönük olarak değerlendirildi. Veriler hastanın demografik özelliklerine, ameliyat ve anestezi süresine, enteral beslenmeye başlama zamanına ve komplikasyonlara göre düzenlendi. Stamm prosedürü için, üst orta hat kesiği ile karın eksplore edildi ve ikinci bir kesiden mide tüpü geçirildi. SILG yönteminde sadece bir kesi yapıldı. Bir trokar içine bir kamera yerleştirildikten sonra, trokarın hemen yanına bir yakalayıcı yerleştirildi. Kesiden midenin bir kısmı çıkarıldı. Lümen içerisine görsel olarak bir foley kateter yerleştirildi.

Bulgular: Her iki cerrahi grup için ameliyat süreleri arasında istatistiksel olarak anlamlı fark yoktu $(\mathrm{p}=0,844)$; aynı durum anestezi süreleri için de geçerliydi $(\mathrm{p}=0,919)$. Tam enteral beslenmeye başlama ve ulaşma süresi iki grup arasında önemli ölçüde farklılık gösterdi $(\mathrm{p}=0,005)$. Genel olarak tüm komplikasyonlar değerlendirildiğinde açık cerrahi grubunda daha fazla komplikasyon saptand $(\mathrm{p}=0,077)$ Her iki grupta da dikkat çekici sayıda $(\% 65,6)$ idame problemi görüldü.

Sonuç: SILG, teknik olarak zorlayıcı olmayan ve laparoskopi deneyimi olan herhangi bir çocuk cerrahı tarafından uygulanabilen bir tekniktir. Trokar giriş yerinde primer laparoskopik gastrostomi, düşük postoperatif komplikasyon oranları nedeniyle malnütrisyonlu tüm çocuklarda kolay ve güvenli bir şekilde yapılabilir ve her yaştaki çocuklara uygulanabilir.

Anahtar kelimeler: Tek kesi laparoskopik gastrostomi; Stamm gastrostomi; çocuk. 


\section{INTRODUCTION}

If adequate nutritional intake within 2-3 weeks is not sufficient in children whose energy and nutritional needs cannot be fully met with only oral nutrition, enteral feeding via a gastrostomy tube (GT) should be considered in children (1). Nowadays, gastrostomy methods are one of the most commonly performed surgical processes in the pediatric patients, and the diseases associated with gastrostomy indications are extensive with the inclusion of neurological, metabolic, cardiopulmonary and urology disorders (2). Since it was first described in 1894, the main approach to gastrostomy has been open gastrostomy, usually using the Stamm technique (3). Percutaneous endoscopic gastrostomy (PEG) tube placement, which was introduced for the first time in 1980 and is a less invasive technique, is still frequently performed in pediatric and adult patients (4). On the other hand, the reporting of serious complications associated with the PEG technique in children led to new searches in pediatric patients and laparoscopic gastrostomy (LG) application gained popularity in the 1990s with the increasing usage of laparoscopy and other video-assisted techniques (5). Since the first time it was applied, LG has undergone different modifications in order to reduce complication rates and facilitate the operation technique (6). Minimally invasive surgery (MIS) has developed rapidly in recent years and has become the gold standard for the correction of many surgical pathologies. Less size of scars, minimum pain (preferentially in a small location), shorter healing time and the desire to seek perfection for an earlier retrieval of daily life quality have led to laparoscopic procedures being performed through a single little incision (7). Various methods such as classical PEG application, fluoroscopyguided gastrostomy opening, and laparoscopic assisted PEG application are used today (8). In our research, we aimed to compare single incision laparoscopic gastrostomy (SILG) with open surgery in children.

\section{MATERIAL AND METHODS}

With the approval of the institutional review board numbered 2020/208, babies and children who had laparoscopic and open surgical gastrostomy surgeries performed in Düzce University Pediatric Surgery Clinic between January 2016 and March 2020 were retrospectively evaluated. The data were arranged according to the patient's age, gender, weight, duration of surgery, duration of anesthesia, time to start enteral feeding, and complications. Complications were considered as intraoperative, major postoperative, and tube care problems. Patients who underwent Nissen fundoplication during the first tube insertion were excluded from the study, and only plain gastrostomy cases were included in the study. Patients who initially had sufficient GT alone but later needed fundoplication were also included in the analysis. Within these criteria, a total of 32 GT placements were evaluated in the analysis. For a long time, an informed consent form, including information that the patient's data can be used, has been routinely obtained from the parents of the patients in all operations.

\section{Operative Technique}

For the open surgery of Stamm procedure, the abdomen was explored with a midline incision above the umbilicus and then the stomach was identified. A second much smaller cut was performed $2 \mathrm{~cm}$ under left costal angle at the anterior abdominal wall, and a gastric tube was passed through it. Gastrostomy was performed by placing a foley catheter in the lumen of the stomach at a suitable place on the anterior surface of the stomach, and closed with a 3-0 polyglactin purse string suture.

In the SILG method, only the second small incision in the classical gastrostomy method was used to reach the peritoneum. The incision was lowered into the peritoneum, opening directly under visualization. After inserting a 5 $\mathrm{mm}$ trocar, abdominal pressures were inflated with carbon dioxide to $6-12 \mathrm{~mm} \mathrm{Hg}$ according to the patient's dimensions and comorbidities. With $5 \mathrm{~mm} 30$ degree camera placed through the port, laparoscopic confirmation of the stomach position and the location of the gastrostomy, a 3-mm grasper was placed just next to the trocar (Figure 1A). A veinless part of greater curvature of stomach was retained (Figure 1B) and, after the trocar pulled out, removed through the incision (Figure 1C). The part of the stomach that was taken out was fixed to the fascia margins of the incision with polyglactin sutures. After the gastrostomy had been opened with cautery, a foley catheter was placed visually into the lumen and the stomach was closed with cerclage suture (Figure 1D). The proper position of the GT was confirmed by intraoperative administration of methylene blue to the stomach and the visualization of the dye from the nasogastric tube.

\section{Statistical Analysis}

Shapiro-Wilk test was used to examine normality assumption, and Independent samples t test was used to analyze numerical variables with normal distribution while Mann-Whitney U test was used for numerical variables not showing normal distribution. Categorical variables were analyzed with Pearson chi-square or Fisher's exact test. Descriptive statistics were given as mean \pm standard deviation or median, interquartile range, minimum, maximum, and categorical variables were summarized with frequency and percentage. Statistical analyses were done by SPSS v.22 statistical package and 0.05 level was considered as statistical significance level.

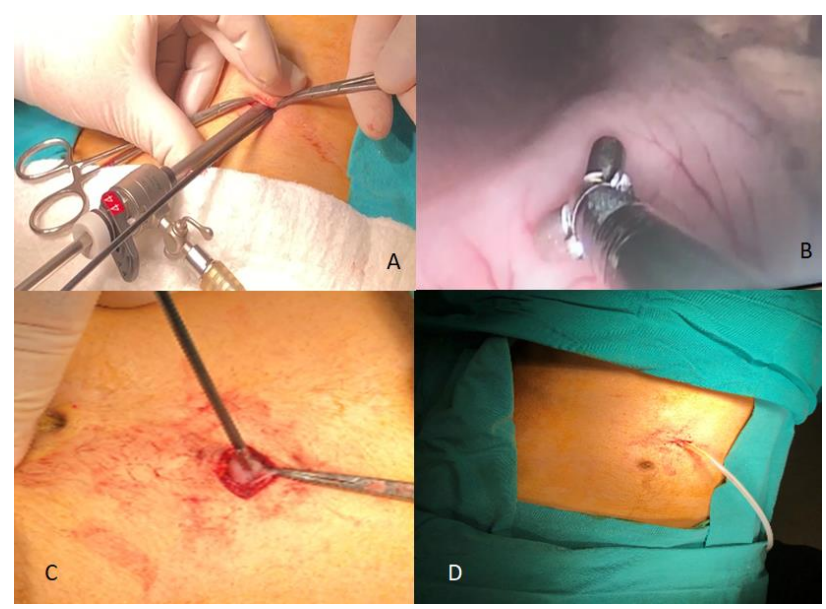

Figure 1. A) A grasper inserted from the side of the trocar in the same incision, B) Easy handling of the stomach from the appropriate non-vascular area with the grasper and, C) after the trocar pulled out, removed through the incision, D) Final state of gastrostomy 


\section{RESULTS}

\section{Study Group}

A total of 32 GTs were placed between January 2016 and March 2020 using the open surgical approach or the SILG placement method. Of these, 17 were open Stamm gastrostomy (53.1\%) and 15 were SILG (46.9\%). The mean age for all patients was $6.4 \pm 5.5$ years and the mean weight was $18.3 \pm 14.8 \mathrm{~kg}$. The age $(\mathrm{p}=0.018)$ and weight $(\mathrm{p}=0.044)$ of the open Stamm gastrostomy patients were found to be higher than the SILG technique. The demographic properties of cases are summarized in Table 1.

Gastrostomy indications were mostly related to growth retardation $(n=26,81.3 \%)$ and nutritional difficulties $(n=22,68.8 \%)$ associated with neurological deficits. Other indications include mental disturbances due to traffic accidents and malignancies. No meaningful differences were found between the surgery groups in terms of procedure indication, gender, and the ratio of patients with neurological disorders or related diagnoses.

\section{Surgical Outcome}

There was no statistically significant difference between operation times for both surgical groups $(\mathrm{p}=0.844)$; the same was true for anesthesia times $(p=0.919)$. It took an average of $53.87 \pm 3.52$ hours for the patients in the SILG group, and $59.59 \pm 6.72$ hours for the patients in the open surgery group to reach full enteral nutrition. The time taken to initiate and reach full enteral nutrition differed significantly between these two groups ( $p=0.005$, Table 2$)$. The launch time of enteral feeding was also different between the groups in favor of SILG ( $\mathrm{p}=0.002$, Table 2).

The GT of a total of 32 patients was replaced with a "low profile" button gastrostomy, and the time elapsed between the operation date and the conversion date did not differ for the two groups. The mean GT replacement time to a button gastrostomy for both groups was $86.4 \pm 6.9$ days. In almost all children, this change was performed in the outpatient clinic with only topical anesthesia or no pain relief. About $76 \%$ of the patients were examined in the follow-up and mean follow-up time was 24.13 \pm 9.68 (range, 10-38) months for SILG group, and 37.94 \pm 16.39 (range, 1-60) months for open surgery group.

\section{Complications}

There was no postoperative death due to the operations in either groups. In general, when all complications were evaluated, more complications were found in the open surgery group $(\mathrm{p}=0.077$, Table 3$)$. Complications were divided into two as intraoperative complications and postoperative complications according to the literature (9). Intraoperative complications were not seen in both the SILG group and the open surgery group. Postoperative complications were also divided into care problems and other complications leading to returning to the operating room. Postoperative complications include intraperitoneal leakage, bleeding, gastric detachment, early separation of the tube, exit from the tube canal, pyloric occlusion and gastrocolic fistula (10). There were exactly 16 postoperative complications were encountered among all gastrostomy patients, 5 (33.3\%) of which were in the SILG group and $11(64.7 \%)$ in the other group $(p=0.077)$. The most important complications in the open surgery group: leakage and pneumoperitoneum were detected in one patient and re-operated in the early period due to gastric separation. In another patient in the same group, the GT was dislodged in the canal, which could not be replaced and required surgery for repair. Just one tube associated with the SILG procedure had this complication and was changed without surgery.

A remarkable figure of maintenance issues $(n=21,65.6 \%)$ was observed in both surgical groups such as tube leakages, impairment in the function of the tube, local infections, skin granulomas, and late dislocations. When operative techniques were compared, there was no difference between the groups in terms of the frequency of these care issues (Table 3). All such complications and care problems were treated with nonsurgical procedures and conservative maintenance.

\section{DISCUSSION}

Nasogastric (NG) tube can be used in a short period in children who cannot be fed orally. Although the NG catheter provides complete enteral nutrition for nutritional purposes, it also has some disadvantages. These disadvantages may arise due to complications experienced during the NG probe insertion phase or long-term use. Complications such as pharyngeal discomfort, nasogastric syndrome, sinusitis, nasotracheal intubation, esophagitis, gastritis, and gastric bleeding may be encountered during the NG catheter insertion phase and in the short period after insertion. More serious complications in children fed

Table 1. Comparison of the demographic properties

\begin{tabular}{cccc}
\hline & $\begin{array}{c}\text { SILG } \\
(\mathbf{n = 1 5})\end{array}$ & $\begin{array}{c}\text { Open Surgery } \\
(\mathbf{n = 1 7 )}\end{array}$ & $\mathbf{p}$ \\
\hline Gender, n (\%) & & & \\
Male & $11(73.3)$ & $9(52.9)$ & 0.234 \\
Female & $4(26.7)$ & $8(47.1)$ & \\
Age (month) & $12(104)[3-180]$ & $108(120)[6-180]$ & $\mathbf{0 . 0 1 8}$ \\
Weight (kg) & $9.5(16.1)[3.5-66]$ & $21(16.8)[5.3-45]$ & $\mathbf{0 . 0 4 4}$ \\
\hline $\begin{array}{l}\text { SILG: single incision laparoscopic gastrostomy, descriptive statistics were given as } \\
\text { median (interquartile range) [minimum-maximum] }\end{array}$
\end{tabular}

Table 2. Comparison of surgical outcomes

\begin{tabular}{lccc}
\hline & $\begin{array}{c}\text { SILG } \\
(\mathbf{n = 1 5})\end{array}$ & $\begin{array}{c}\text { Open Surgery } \\
(\mathbf{n = 1 7})\end{array}$ & $\mathbf{p}$ \\
\hline Operation time (min) & $32.60 \pm 8.23$ & $33.12 \pm 6.56$ & 0.844 \\
Anesthesia time (min) & $47.00 \pm 8.43$ & $47.29 \pm 7.88$ & 0.919 \\
Starting time of & $21.33 \pm 2.09$ & $29.06 \pm 8.25$ & $\mathbf{0 . 0 0 2}$ \\
$\begin{array}{l}\text { Enteral Nutrition (h) } \\
\text { Starting time of Total }\end{array}$ & $53.87 \pm 3.52$ & $59.59 \pm 6.72$ & $\mathbf{0 . 0 0 5}$ \\
Enteral Nutrition (h) & & &
\end{tabular}

SILG: single incision laparoscopic gastrostomy, descriptive statistics were given as mean \pm standard deviation

Table 3. Comparison of complications, n (\%)

\begin{tabular}{lccc}
\hline & $\begin{array}{c}\text { SILG } \\
(\mathbf{n = 1 5})\end{array}$ & $\begin{array}{c}\text { Open Surgery } \\
(\mathbf{n = 1 7 )}\end{array}$ & $\mathbf{p}$ \\
\hline $\begin{array}{l}\text { Intraoperative } \\
\text { complications }\end{array}$ & - & - & - \\
$\begin{array}{l}\text { Postoperative } \\
\text { complications }\end{array}$ & $5(33.3)$ & $11(64.7)$ & 0.077 \\
$\begin{array}{l}\text { Return to operating room } \\
\text { Maintenance issues }\end{array}$ & $0(0.0)$ & $2(11.8)$ & 0.486 \\
\hline SILG: single incision laparoscopic gastrostomy & $11(64.7)$ & 0.907 \\
\hline
\end{tabular}


with NG catheter for a long time; erosion of the nasal wings, knotting of the catheter in the esophagus or stomach, GER, pneumothorax, tracheoesophageal fistula may develop (11). For these reasons, gastrostomy techniques have been developed and started to be used as the gold standard in patients with chronic diseases where NG cannot be used for a long time. Open Stamm gastrostomy was the most widely used method until the invention of the PEG technique which has been found after long years usage of open surgery. However, with the reporting of major problems associated with the PEG procedure in children, it has increased anxiety about the reliability and usefulness of this approach in the pediatric population. Because it requires the PEG tube to be blindly inserted from the peritoneal cavity into the stomach, creating a harmful potential to the surrounding viscera. After the discovery of laparoscopy and with the improvement of smaller devices, a large variety of surgical disorders in children, including gastrostomy, have been corrected with this surgical technique (12).

In the last 20 years, studies including laparoscopy-assisted gastrostomy experiences have been published. After these methods involving 2-3 ports, as technology and innovation continue to advance the field of MIS, single incision laparoscopic surgery (SILS) for a variety of general, bariatric, urological and pediatric surgical procedures is gaining popularity as a method to achieve a less "scar-free" abdomen. Compared to the traditional laparoscopic procedure, the single-site technique can be considered less invasive as it uses only one incision instead of 2 or 3 . A number of reports have been published in the literature regarding the feasibility of SILS in various techniques in adults. However, there are very few studies on the usage of this new technique in children (13).

Before the procedure was decided, abdominal USG was absolutely performed in patients, and if anomalies such as hepatomegaly or splenomegaly were present, open surgery was preferred to avoid laparoscopy complications. Open surgery was also preferred in patients who had previously undergone intra-abdominal surgery or in the presence of conditions that prevent gastric mobilization, such as previous TEF operation, and in patients with lung problems that limit laparoscopy. In such patients with suspected adhesion, single port surgery is risky and 2, 3 or even 4 ports may be required (14), which prolongs the operation time and decreases the feasibility compared to open surgery. That's why we preferred the open approach in such cases.

Previously published studies comparing laparoscopic and open GT implantation but involving mostly adult patients could not show a statistically important difference in the rate of postoperative complications or tube revising (15). In our study, we did not encounter intraoperative complications in either group. However, the rate of postoperative complications was surprisingly higher in the open surgery group (33.3\% and $64.7 \%$, respectively). The two patients who were re-operated were in the open surgery group. On the other hand, this has been attributed to other patient-related situations rather than the methods employed. The patient, who was re-operated due to gastric detachment, had severe scoliosis. In the other patient whose catheter could not be inserted under polyclinic conditions, her parents applied to the hospital too late and the tract was closed. In any case, the laparoscopic procedure may have prevented such complications as it provides better visualization of the whole intraabdominal space and reduces the risk of wound dehiscence.

One more advantage of working under direct visualization is the opportunity to select a sensitive site for the appropriate gastric hole for tensionless connection to the abdominal wall. Thus, one of the major advantages of the SILG technique is the avoidance of critical complications such as unwanted injury to abdominal organs, like the insertion of the gastrostomy into the colon or liver and unforeseeable hemorrhages. So, the technique can replace other gastrostomy techniques, especially in young babies and toddlers. Compared to PEG, the simplicity and practicability of this single-site laparoscopic technique could potentially become the first choice technic for GT installment in young children. In our patient series, the SILG method was applied to patients between 3 months and 15 years old patients, there is no difficulty in choosing the age, and it can be easily applied to children of all ages. When compared in terms of tube maintenance problems, there was no difference between the two surgical groups. Similar problems were encountered in both groups and similar maintenance intervals were required. However, we experienced that tube changes can be done more easily in the SILG group. We think that this is because the stomach is fixed to the fascia in the SILG method. Likewise, the inability to reattach in case of involuntary tube dislocation was not observed in the SILG group, while one patient had to be re-operated because of this reason in the open surgery group.

On the other hand, the SILG technique is not applicable to every child and the risks associated with each surgical procedure vary depending on the characteristics of the patients and accompanying health situations. For instance, the pressure of the gas given during laparoscopy can be dangerous in any children with lung diseases. Furthermore, records of previous intraabdominal surgery especially the upper region could challenge the surgeon during laparoscopic surgery (16).

There were no statistically significant differences between the two surgical groups according to operation times and anesthesia durations. In the comparisons in the literature, generally laparoscopic methods were found to be longer in both times. We believe that the use of a single port in the SILG method, unlike other laparoscopic methods, has an effect on finding these times shorter. In addition, there was no difference between the open surgery group and the SILG group in terms of feasibility due to the use of a single trocar, single telescope and single grasper during the procedure, all of which are reusable.

Pain-related discomfort has been the subject of discussion when discussing laparoscopic techniques with a single incision. The hypothesis is that the larger the facial incision, the more pain the patient will experience. However, when we scan the patient files regarding the use of painkillers, we found no significant distinction between the two gastrostomy groups in terms of narcotic drugs or anti-inflammatory medication.

\section{CONCLUSION}

SILG is a technique that is not technically demanding and can be performed by any pediatric surgeon with experience 
in laparoscopy. Primary LG at the trocar insertion site can be performed easily and safely in all children with malnutrition due to low postoperative complication rates and applicable for all ages of children.

Ethics Committee Approval: The study was approved by the Ethics Committee of Düzce University Faculty of Medicine (21.09.2020, 208).

Conflict of Interest: None declared by the authors.

Financial Disclosure: None declared by the authors.

Acknowledgements: None declared by the authors.

\section{REFERENCES}

1. Löser C, Aschl G, Hébuterne X, Mathus-Vliegen EM, Muscaritoli M, Niv Y, et al. ESPEN guidelines on artificial enteral nutrition--percutaneous endoscopic gastrostomy (PEG). Clin Nutr. 2005;24(5):848-61.

2. Baker L, Beres AL, Baird R. A systematic review and meta-analysis of gastrostomy insertion techniques in children. J Pediatr Surg. 2015;50(5):718-25.

3. Stamm M. Gastrostomy by a new method. Med News. 1894;65:324-6.

4. Gauderer MW, Ponsky JL, Izant RJ Jr. Gastrostomy without laparotomy: a percutaneous endoscopic technique. J Pediatr Surg. 1980;15(6):872-5.

5. Edelman DS, Unger SW, Russin DR. Laparoscopic gastrostomy. Surg Laparosc Endosc. 1991;1(4):251-3.

6. Kaya M, Sancar S, Ozcakir E. A new method for laparoscopic Stamm gastrostomy. J Laparoendosc Adv Surg Tech A. 2018;28(1):111-5.

7. Sayadi Shahraki M, Berjis N, Bighamian A, Mahmoudieh M, Shahabi Shahmiri S, Sheikhbahaei E. Minimally invasive technique for gastrostomy tube insertion: A novel laparoscopic approach. Asian J
Endosc Surg. 2020;13(4):610-3.

8. Akay B, Capizzani TR, Lee AM, Drongowski RA, Geiger JD, Hirschl RB, et al. Gastrostomy tube placement in infants and children: is there a preferred technique? J Pediatr Surg. 2010;45(6):1147-52.

9. Sandberg F, Viktorsdóttir MB, Salö M, Stenström P, Arnbjörnsson E. Comparison of major complications in children after laparoscopy-assisted gastrostomy and percutaneous endoscopic gastrostomy placement: a meta-analysis. Pediatr Surg Int. 2018;34(12):1321-7.

10. Sulkowski JP, De Roo AC, Nielsen J, Ambeba E, Cooper JN, Hogan MJ, et al. A comparison of pediatric gastrostomy tube placement techniques. Pediatr Surg Int. 2016;32(3):269-75.

11. Sano N, Yamamoto M, Nagai K, Yamada K, Ohkohchi N. Nasogastric tube syndrome induced by an indwelling long intestinal tube. World J Gastroenterol. 2016;22(15):4057-61.

12. Merli L, De Marco EA, Fedele C, Mason EJ, Taddei A, Paradiso FV, et al. Gastrostomy placement in children: percutaneous endoscopic gastrostomy or laparoscopic gastrostomy? Surg Laparosc Endosc Percutan Tech. 2016;26(5):381-4.

13. Hansen EN, Muensterer OJ, Georgeson KE, Harmon CM. Single-incision pediatric endosurgery: lessons learned from our first 224 laparoendoscopic single-site procedures in children. Pediatr Surg Int. 2011;27(6):643-8.

14. Kandil E, Alabbas H, Jacob C, Friedlander P, Duchesne J, Joshi V, et al. A simple and safe minimally invasive technique for laparoscopic gastrostomy. JSLS. 2010;14(1):62-5.

15. Mizrahi I, Garg M, Divino CM, Nguyen S. Comparison of laparoscopic versus open approach to gastrostomy tubes. JSLS. 2014;18(1):28-33.

16. Peters RT, Balduyck B, Nour S. Gastrostomy complications in infants and children: a comparative study. Pediatr Surg Int. 2010;26(7):707-9. 